\title{
Engaging leadership training - fostering social interaction skills through e-learning and blended solutions
}

\author{
Kirsti Lonka $^{\text {ab1 }}$, Elina Ketonen ${ }^{a}$, Kitte Marttinen ${ }^{c}$, Markus Talvio $^{a}$ \\ ${ }^{a}$ Faculty of Educational Sciences, University of Helsinki \\ ${ }^{b}$ Optentia Research Focus Area, Vaal Triangle Campus, North-West University \\ ${ }^{c}$ Hagag Helia University of Applied Sciences
}

\begin{abstract}
The Engaging Learning Environment (ELE) model was introduced into a company's work-place to support the learning and well-being of the employees. The participants were 107 middle managers: E-learning group $(n=42)$ and a comparison group $(n=42)$ as well as a blended ELE intervention group $(n=23)$ assigned by the company that combined e-learning and face-to-face sessions. All groups participated in pre- and post-tests. The participants' knowledge was assessed by 16 MCQs and their application skills by the Dealing with Challenging Interaction (DCI) method which consisted of case studies. The descriptions of how to act in case situations were content analysed. A repeated measures GLM was used to determine whether knowledge and skills changed during the leadership training, and whether their belonging to one of the groups had any bearing on this. The analysis showed that the e-learning group improved their performance more than the comparison group and the results of the ELE intervention group improved even more. Therefore, it is possible to learn communication skills online.
\end{abstract}

Keywords: e-learning, blended learning, leadership, training, social interaction skills, online learning

\section{Introduction}

This article looks at how to encourage middle managers' workplace learning, by using modern pedagogical approaches. We believe that training in management and leadership could greatly benefit from current research on learning

Faculty of Educational Sciences, PO BOX 9, 00014 University of Helsinki, Finland; kirsti.lonka@helsinki.fi 
and instruction. The new Finnish national curriculum emphasises the need for modern broad-based expertise that includes working life skills, as well as entrepreneurship and ICT skills (Lonka, 2018). Our intention is to educate a new generation of citizens who are fluent in learning such skills. Our challenge, however, is to educate the existing workforce on how to deal with complex and ill-defined problems that confront them on a daily basis.

Workplace learning is a complex and multi-dimensional phenomenon (Tynjälä, 2008, 2013). There are many tacit knowledge and social practices involved that are difficult to put in a formal and literate form, especially leadership skills that involve the leader's ability to solve very complex and contextual social problems that arise in organisations (Mumford, Zaccaro, Connelly, \& Marks, 2000). Modern socio-constructivist theories emphasise the importance of the integrative pedagogy to address the identity and roles of the whole community and workplace practices (Tynjälä, 2008; Wenger, 1999). Today the ideas of networked, systemic and distributed learning have become increasingly popular, since many complex problems call for collaborative efforts and smart tools (Hakkarainen, Palonen, Paavola, \& Lehtinen, 2004; Trilling \& Fadel, 2009). Technology and digitalisation can change learning only if the knowledge practices of the workplace can be modified.

In his seminal work, Knowles (1980) stated that adults' previous experiences are a rich resource for learning. Adult education programs should therefore be organised around 'life application' categories and sequenced according to the learners' readiness to learn. Further, adults wish to apply newly acquired skills or knowledge to their present situation. Adults often learn more effectively through experiential techniques of education, especially when communications skills are in question (Aspegren, 1999; Kolb, 1984). Many workplace skills are difficult to teach by lecturing. Integrative pedagogy that applies processoriented methods, such as problem-based, project-based and case-based learning methods have been recommended to enhance workplace learning (Tynjälä, 2008).

\section{How do you engage learners?}

Our pedagogical approach is based on a synthesis of previous models of process-oriented, student-activating and experiential learning approaches (Bereiter \& Scardamalia, 1993; Kolb, 1984; Lonka \& Ahola, 1995; Vermunt, 1995). In addition, our Engaging Learning Environment (ELE) also includes the modern psychology of learning, motivation and emotion (e.g., Muis et al., 2015; Pekrun, 2005). The four-phase model of interest by Hidi and Renninger (2006) is an essential part of this model: First, situational interest is 1) created, then 2) maintained into 3) deepened into personal interest, and the goal is to 
motivate the participants for 4) long-term personal interest. ELE involves a gradually deepening learning cycle, typical of many theories of adult learning (Kolb, 1984; Mezirow, 1991). We wanted to develop both an online and a blended learning environment that takes into account the previous models of effective, meaningful and motivating learning practices that are well known to many adult educators.

The ELE model (Lonka, 2012, 2018) builds on the strengths of the participants. The learning cycle always starts with a pre-test followed by the stages below:

1. Activating prior knowledge and triggering interest. During this phase, the most important thing is to provide a meaningful context, where the current challenges of the workplace are diagnosed and shared. The intention is to find out what people already know and how they would put this into practice. In blended learning, we start with a face-to-face learning situation in order to establish trust, to get to know each other and to gauge the interest of the participants.

2. Supporting the learning process and maintaining interest. Here, online modules are applied, where information is easily available and the participants may deepen their understanding and test their learning. Video clips, that demonstrate how to deal with varying situations, may be provided. Networking and peer discussions with other participants are encouraged, either online or face-to-face. Constant feedback is provided, developing the progress of the learning process. Experiential learning methods are used especially in blended learning conditions where communication skills may be trained in interaction with other people (e.g., professional actors are used to act in the video clips).

3. Assessing change and motivating for future learning. Here, evaluation and post-tests take place, where we look at what was being learned, how well the process went and how to inspire the participants to put their knowledge into practice.

During training, conceptions of knowledge and learning (i.e. epistemic beliefs) may develop from seeing learning as memorising or intake of knowledge into seeing learning as applying, understanding or constructing knowledge. The highest levels of epistemic beliefs involve seeing learning as adopting new perspectives or changing as a person (Marton, Dall'Alba, \& Beaty, 1993). Recently, conceptions of learning have turned towards collaborative knowledge construction as the rapidly changing, digital and dynamic environment sets new demands on intensive team work (Lonka, Olkinuora, \& Mäkinen, 2004). We showed that during blended ELE leadership training, even epistemic change took place: the managers became increasingly willing to reflect on their 
own actions and they began to see the practical value of leadership training (Ketonen, Talvio, \& Lonka, 2014).

\section{Leadership skills to promote motivation and well-being}

It has been illustrated how managerial practices often have unintended or even negative consequences for the employee's well-being (Grant, Christianson, \& Price, 2007). Transformational leaders are expected to go beyond exchange relationships and motivate others to achieve more than they thought was possible (Bass \& Riggio, 2006). Some studies of the relationship between transformational leadership and psychological well-being found that transformational leadership exerted a positive influence on the psychological well-being of workers (Arnold, Turner, Barling, Kelloway, \& McKee, 2007). Learning is therefore not only cognitive, but also motivation plays an important role: it should be intrinsic or autonomous rather than extrinsic or controlled (e.g., Gegenfurtner, Veermans, Festner, \& Gruber, 2009; Ryan \& Deci, 2002). Emotions also play a role in learning, such as interest and curiosity (e.g., Hidi \& Renninger, 2006; Muis et al., 2015; Pekrun, 2005). It is of interest, how to promote both well-being and meaningful learning in the work place.

Many leadership models emphasise personal change and transformation instead of just leadership skills on their own. However, promoting well-being and motivating others are extremely complex social skills that are not easily learned (Talvio, 2014).There are meaningful ways of learning central leadership skills, such as Gordon's Leader Effectiveness Training that helps to learn some crucial communication skills, for instance, listening and conflict resolution skills (Gordon, 2001; Leader effectiveness training, $n$. d.). There is however, little evidence of their impact.

Research on expertise is also a relevant approach to workplace learning (Tynjälä, 2013). Expertise is mostly domain specific and it is related to a certain area of expertise (Ericsson \& Lehmann, 1996; Ericsson \& Smith, 1991). Experts in various areas have declarative knowledge, "knowing that", which is factual in nature and easily verbalised. During the development of expertise, their knowledge should transform into procedural knowledge that refers to "knowing how." Such knowledge is often inert in nature: hard to teach, learn and assess (Renkl, Mandl, \& Gruber, 1996).

High quality leadership has the potential to positively influence others' psychological well-being (van Dierendonck, Haynes, Borrill, \& Stride, 2004). It is obviously time to move away from leadership development programmes emphasising knowledge input over interaction (Hotho \& Dowling, 2010). However, surprisingly little is known about the effect of online training on the well-being and social interaction skills of leaders and middle managers. 


\section{Social interaction training at work}

The problem of putting a strategy into action may lie in the beliefs of the managers about the nature of expertise and how it should be encouraged. Many abilities such as "talent", "IQ", "emotional intelligence", "personality traits" and "charisma", may represent teachable and learnable skills (Ericsson, Prietula, \& Cokely, 2007). The readiness to deal with leadership issues calls for intentional effort. Dweck (2006) used the term "fixed mindset" to look at a set of beliefs that reduced complex skills into traits and innate abilities. In contrast, "growth" mindset referred to successfully dealing with complex tasks such as dealing with challenging interactions in the work place (ibid.). In the context of growth mindset, errors would not be signs of failure, but as sources for learning and development. Group dynamics are very complicated, and people may have difficulties in seeing their own contribution in them. In our previous study, we showed that during blended ELE leadership training the fixed mindset conceptions did decrease during training, indicating that growth mindset may be encouraged by engaging the participants to learn how to deal with complex interactions (Ketonen et al., 2014).

Evidence supports that, in other contexts, communication skills can be learned and taught. Many of these studies have been carried out in the area of medicine (e.g., Aspegren, 1999; Brown \& Bylund, 2008): basic skills can be learnt in a short period of training, and men are sometimes slower learners of communication skills than women. Regardless of research evidence, little effort has been made to provide an overarching framework for organising the training of communication skills (Cegala \& Broz, 2002).

The benefits of teachers' social interaction training have also been shown, for instance, in the context of a four-day Gordon's Teacher Effectiveness Training (Gordon, 2003; Teacher effectiveness training, $n$. d.). Overall, the outcomes of TET were positive (Talvio, 2014; Talvio, Ketonen, \& Lonka, 2014; Talvio, Lonka, Komulainen, Kuusela, \& Lintunen, 2015). The participants' skills studied during TET such as listening skills, autonomy supporting behaviour and the readiness to confront in a constructive way improved during the course. Further, undesired ways of interacting decreased significantly. In the comparison group, no significant differences between pre- and post-test scores were found in knowledge, skills, or overall well-being levels. The effects of TET lasted nine months after completing the course: most participants described the methods of applying the acquired skills and most of the participating teachers would have recommended the training to their colleagues. (Talvio et al., 2014) Obviously, having the working group at the same training helped participants to maintain the learned knowledge and skills. 
Knowledge and skills are in many cases intertwined, since relevant knowledge is needed for problem solving, and expertise is highly domain specific (Hodges, 2006). For example, in our previous study (Talvio, Lonka, Komulainen, Kuusela, \& Lintunen, 2013) the teachers' knowledge of communication skills and competence to apply them correlated well with each other. However, even a high level of knowledge does not necessarily guarantee skilled actions in practical situations. The studied knowledge might be irrelevant or difficult to put into action. Management and leadership skills typically involve lots of procedural and practical problem solving, that is ill-defined, complex and contextual in nature, and the problems to be solved are in many cases social (Mumford et al., 2000; Tynjälä, 2008).

\section{Blended learning and e-learning in higher education and leadership training}

Parallel to theories of learning and leadership, technologies have gone through major transformations during recent decades. "Educational technology" has turned into computer-supported collaborative learning (CSCL): instead of individual learning, collaborative knowledge creation is the goal (e.g., Paavola, Lipponen, \& Hakkarainen, 2004). E-learning has been increasingly merged with face-to-face learning and the terms "blended" or "hybrid" environments are common in higher education (Bonk \& Graham, 2006). Our own concept Engaging Learning Environment (ELE) refers to a holistic pedagogical model in a hybrid/blended learning environment combining physical, virtual, mobile, social, pedagogical and mental spaces of learning (Lonka, 2012; Sandström, Eriksson, Lonka, \& Nenonen, 2016).

E-learning is usually defined as the use of different ICT technologies in learning, while blended learning environments are usually defined as learning environments which combine face-to-face learning with e-learning (e.g., Bonk \& Graham, 2006). Recently in Finland, new blended learning initiatives have been launched into higher education (Marttinen, Patala, Ketonen, Ruusunen, \& Lonka, 2012). The use of ICT technologies in learning, as well as in cooperation with work life, shows that the use of educational technology must be increased and teachers should be trained to use it to a higher degree. Even if the younger generation is more familiarised with technologies and students appreciate online education, to ensure the success of an online course, an effective course design using a student-centred model, delivery and assessment is needed (Mortagy \& Boghikian-Whitby, 2010).

The use of e-learning in education is world-wide and teaching and learning practices have been increasingly transferred into the e-learning environ- 
ment. However, face-to-face learning still has its benefits. Paechter and Maier (2010) indicated in their study that when students needed to acquire skills in self-regulated learning they advocated online learning, but wanted face-to-face instruction for knowledge and skills. Worker's attitudes and perceptions were analysed among 2000 bank employees (Batalla-Busquets \& Pacheco-Bernal, 2013). The results showed that e-learning was seen as a more flexible and up-to-date training methodology, whereas face-to-face training was perceived as more motivating. We assumed that benefits from both face-to-face learning and e-learning, at their best, can be adapted to the innovative blended learning environment, such as ELE. We have applied the Engaging Learning Environment (ELE) model in collaboration with the Finnish Economic Information Office (TAT) in seven e-learning courses "Young Business Generations" to promote the business and working life skills of Finnish high-school students. These courses can be applied, in collaboration with the teachers, either as mere e-learning environments or as a blended learning environment (Vaara, 2018).

As the role of modern managers changes from controlling to more supporting and engaging (Hlupic, 2014), also the management training as well as other on-the-job training should be adapted to the reality of a modern work-environment. Grossman, Salas, Pavlas and Rosen (2013) used instructional features to enhance demonstration-based training in management education. Wall and Ahmed (2008) showed among construction professionals that the instructor and classroom instruction played an important role in the delivery of blended learning. They highlighted the importance of planning informal events in addition to formal instruction. Their case study illustrated that blended learning programmes can engage construction professional by using a range of ICT technologies and the integration of these technologies can make for an effective programme. (Ibid.) However, even if e-learning is increasingly used in the work-environment, the role of face-to-face learning cannot be underestimated. There is a need to develop and engage both e-learning and blended learning environments into management training.

\section{Context of the study}

A major insurance company in Finland was implementing an organisational change process. The aim of our collaboration was to create an e-learning and a blended learning environment by developing an innovative leadership training for the middle management. The intention was to utilise Engaging Learning Environment (ELE) model (Lonka, 2012, 2018; Lonka \& Ketonen, 2012) for the training, focusing on supporting the well-being and working conditions of the employees. 
Our challenge was to help middle managers of a large insurance company who were experts in their specific areas (lawyers, business people or engineers) to implement the new corporate strategy. In order to put successfully the strategy into action they needed to have the relevant knowledge. They also needed to know about the recommended procedures and practices of different cases regarding varying leadership issues, such as sick leave and their employees' well-being. This called for complex communication skills. Middle managers also faced various challenging interaction situations in this work. Knowledge about strategy can be difficult to apply in the workplace. Communication skills are not the result of knowing the strategy, but a declarative knowledge that should be turned into expert know-how. This paper describes how the pedagogical challenge was achieved and if there was any evidence of the goals being met in terms of how the middle managers learned to deal with challenging interactions in the workplace.

During the training, we studied the possibility of changes to the participants' knowledge and skills on how to learn and deal with challenging interactions. We also wanted to compare the outcomes of ELE E-learning group (e-learning only) and the comparison group with each other. We also wanted to look at the benefits of the intensive ELE intervention (blended training). Two research questions were addressed in this study:

1) Would participants in the E-learning group report significantly higher levels of knowledge about the corporate strategy on occupational health and wellbeing of the company and their readiness to deal with challenging interaction (application of knowledge) after the training, than those in the comparison group?

2) Would adding the face-to-face element by blended ELE leadership training promote learning even more?

\section{Method}

\section{The intervention}

In the present study we focused on the middle managers' knowledge about the strategy of their company on occupational health and their readiness to apply this knowledge in challenging interaction situations. Identical questionnaires were given to participants in August (pre-test) and at the end of October (post-test) to examine any possible changes to the above-mentioned measured outcomes.

From the same major insurance company, there were two randomised groups: 1) E-learning group $(n=42)$ who had access to the online materials 
and 2) a comparison group $(n=42)$ who only filled in the questionnaires. In addition, there was 3$)$ a blended ELE intervention group $(n=23)$ that was assigned by the company (these participants could not be randomised), who went through the process that combined the online learning and the face-toface sessions. They were selected by the HR who believed these individuals had a promising future with the company.

Managers chosen by the insurance company were given a blended cyclic knowledge advancement process of ELE to encourage their organisational change process. The ten-week process started in August and finished in October. Accommodation, meals and travel expenses of those managers who attended were paid for by the company, plus all were away from their workplace during this period, incurring a substantial financial commitment from the company. The company's intranet was used as the online environment and the face-to-face training took place in the workplace. In addition, online chat meetings took place.

During the first phase (catching interest) current knowledge was examined and activated in a meaningful context to guide and direct learning. A face-toface session kicked off in mid-August. All participants were well acquainted with the corporation's new strategy, but they had some misgivings as how to implement it. The second phase (maintaining interest) consisted of individual online studies prepared by the HR and the ELE team. In mid-September a series of online studies and chat meetings were integrated with a six-hour faceto-face workshop directed by the ELE head trainer and a group of professional actors who demonstrated challenging situations to the participants. In the third phase of the ELE process (assessing learning gains, motivating future learning) knowledge produced and learning gains were assessed to engage participants in deepening their inquiry and interest levels. The final session took place at the end of October.

\section{Participants}

The participants were from a major Finnish insurance company and consisted of 107 middle managers aged 27 to $63(M=46.8, S D=8.4) .69 .7 \%$ of these participants were female and $30.3 \%$ were male. On an average, the participants had 7.7 years of working experience as a manager in the company but the variation was quite large $(S D=6.9)$. The average of the manager experience in general (in different companies combined) was 10.3 years, also varying quite a lot $(S D=8.6)$.

We conducted a chi-square test on categorical (gender) and an ANOVA test on continuous (age, manager experience, scores on knowledge and knowledge 
application) variables to determine whether there were differences between groups prior to training that would potentially influence the results. We found no statistically significant differences between the three groups' background information (i.e., age, gender, managerial experience), scores on knowledge and knowledge application measured before the ELE training.

\section{Instruments and procedure}

\section{Knowledge about the strategy on occupational health and well-being}

In the pre- and post-questionnaire, a total of 16 multiple choice questions were asked to ascertain the participants' knowledge of managing their employees' occupational health and well-being. Each question had 3-7 alternative answers that the participants considered to be right or wrong. There were nine questions of general managing issues, such as the roles and responsibilities of the manager, how to handle a decline in the workforce's well-being and quality of work, what is bullying, how accidents at work can be prevented, and why it is important to take care of the employees' well-being. There were seven additional questions that examined the knowledge of the goals and rules that are central to the human resources management of the investigated company. The rating scale varied between 0 (demonstrating poor knowledge) to 70 (demonstrating excellent knowledge). This knowledge test was created by the HR of the company and it measured various dimensions of knowledge about the new strategy. It was not assumed that the questions would be a coherent scale.

\section{Knowledge application in challenging interaction}

The knowledge application in challenging interaction situations was tested by utilising the Dealing with Challenging Interaction (DCI) method (Talvio, Lonka, Komulainen, Kuusela, \& Lintula, 2012; Talvio et al., 2013). The questionnaires also included cases of challenging situations that managers need to handle with their employees. After presenting each case the participants were asked to describe in a few lines on how they would react. For example: "The quality of work and the productivity of one of your employees have declined. The projects that he is involved with are behind schedule and he refuses to take responsibility. To keep the clients satisfied, your colleagues have been forced to take care of his projects. How would you react?" (Case 1, declining productivity). The other two cases were about discussing the employee's excessive working days, withdrawing from others' company, and unexplained absence from work (Case 2, changed behaviour) and confronting the work 
community about lack of respect and a bad atmosphere among employees (Case 3, poor atmosphere).

The descriptions of the intended action given by the participants were content analysed and quantified by rating the answers on the scale from one to five according to the interpersonal quality of the response (see Frey, Botan, Friedman, \& Kreps, 1992; Talvio et al., 2012; Weber, 1990). For example, only one point was given when the answer contained no dialogue and just directive talk, whereas full five points were given if the answer was reciprocal in nature, for example, including descriptions of listening and supporting the autonomy and agency of the employee. The answers to all three cases were independently rated by an external pedagogue and an external communication skills trainer, in parallel, before and after the training. In addition, the head trainer of the ELE training analysed the answers of Case 1. The raters did not know if the answer was given before or after the training and whether the participant belonged to the ELE, E-learning or comparison group.

In each case, Cronbach's alphas were calculated to determine the internal consistency of the raters. In Case 1, the alpha was .73 in the pre-test and .64 in the post-test, indicating adequate reliability of the combined ratings of the three independent raters. In Cases 2 and 3, Cronbach's alphas were .69 and .67 in the pre-test and .77 and .71 in the post-test, respectively. Hence, the independent ratings of the qualitative cases showed moderate to good internal consistency among the raters and consequently sufficient reliability in the quantification of each case.

\section{Analyses}

All the analyses were implemented using IBM SPSS Statistics version 24.0. The mean scores and the standard deviations for the pre- and post-tests for each group were calculated. A repeated measures General Linear Model (GLM) was carried out in four separate models in order to determine whether participants' knowledge and knowledge application (in three cases) would change during the leadership training (main effect), and whether their belonging to ELE, E-learning or the comparison group had any bearing on such changes (interaction). In each model, the knowledge or knowledge application (case) variable was added as a dependent variable, group membership and leadership training (pre- and post-tests) as independent variables (between subjects and within-subject independent variables). All the variables were added into the models at the same time, and the main effect of training, as well as the interaction between group and training of knowledge and knowledge application, was investigated simultaneously. Furthermore, pairwise comparisons with 
Bonferroni adjustment were conducted to further examine in which particular groups the difference between the means of pre- and post-tests was significant. In the statistical analyses, the largest possible number of participants were included in each analysis.

\section{Results}

No statistically significant differences were found, in any of the cases, between the ELE, E-learning and comparison group before the ELE training for scores on knowledge or knowledge application. Furthermore, all groups had high scores on knowledge prior to the training (close to 60 points on a scale varying from 0-70 (see Table 1 for detailed descriptive statistics).

Table 1. Descriptive statistics

\begin{tabular}{|c|c|c|c|c|c|c|c|c|c|c|c|c|}
\hline \multirow[b]{3}{*}{ Variable } & \multicolumn{4}{|c|}{$\begin{array}{c}\text { ELE } \\
\text { intervention group } \\
n=23\end{array}$} & \multicolumn{4}{|c|}{$\begin{array}{l}\text { E-learning group } \\
\qquad n=42\end{array}$} & \multicolumn{4}{|c|}{$\begin{array}{c}\text { Comparison group } \\
n=42\end{array}$} \\
\hline & \multicolumn{2}{|c|}{ pre-test } & \multicolumn{2}{|c|}{ post-test } & \multicolumn{2}{|c|}{ pre-test } & \multicolumn{2}{|c|}{ post-test } & \multicolumn{2}{|c|}{ pre-test } & \multicolumn{2}{|c|}{ post-test } \\
\hline & $M$ & $S D$ & $M$ & $S D$ & $M$ & $S D$ & $M$ & $S D$ & $M$ & $S D$ & M & $S D$ \\
\hline Knowledge & 60.7 & 3.6 & 62.8 & 4.9 & 59.5 & 5.8 & 61.1 & 5.7 & 59.3 & 5.0 & 59.8 & 3.5 \\
\hline \multicolumn{13}{|l|}{$\begin{array}{l}\text { Knowledge } \\
\text { application }\end{array}$} \\
\hline Case 1 & 3.26 & .75 & 3.91 & .65 & 3.18 & .77 & 3.69 & .69 & 3.29 & .83 & 3.20 & .66 \\
\hline Case 2 & 3.02 & .55 & 3.79 & .98 & 2.92 & .87 & 3.21 & .86 & 3.06 & .92 & 3.00 & .75 \\
\hline Case 3 & 2.89 & .83 & 3.22 & 1.03 & 3.01 & .90 & 3.12 & .92 & 3.06 & .91 & 3.18 & .92 \\
\hline
\end{tabular}

\section{Change in knowledge with regard to the strategy on occupational health and well-being}

To address the first research question a repeated measures GLM was conducted with the score measuring knowledge being the dependent variable The results revealed that overall, the positive effect of training on knowledge scores was statistically significant $\left[F(1.77)=11.07, p=.001\right.$, partial $\left.\eta^{2}=.126\right]$. Pairwise comparisons demonstrated a significant difference between pre- and post-tests within the ELE intervention group $\left[F(1.77)=5.42, p=.022\right.$, partial $\left.\eta^{2}=.066\right]$ and the E-learning group $\left[F(1.77)=8.91, p=.004, \eta^{2}=.104\right]$ but not for the comparison group $\left[F(1.77)=.08, p=.784, \eta^{2}=.001\right]$, indicating that the training had a positive effect on the ELE-intervention group and E-learning group 
(see Figure 1). Thus, the scores of both the ELE and the E-learning group changed significantly between pre- and post-tests in terms of increasing knowledge of the company's strategy regardless of the high level of knowledge before the training.

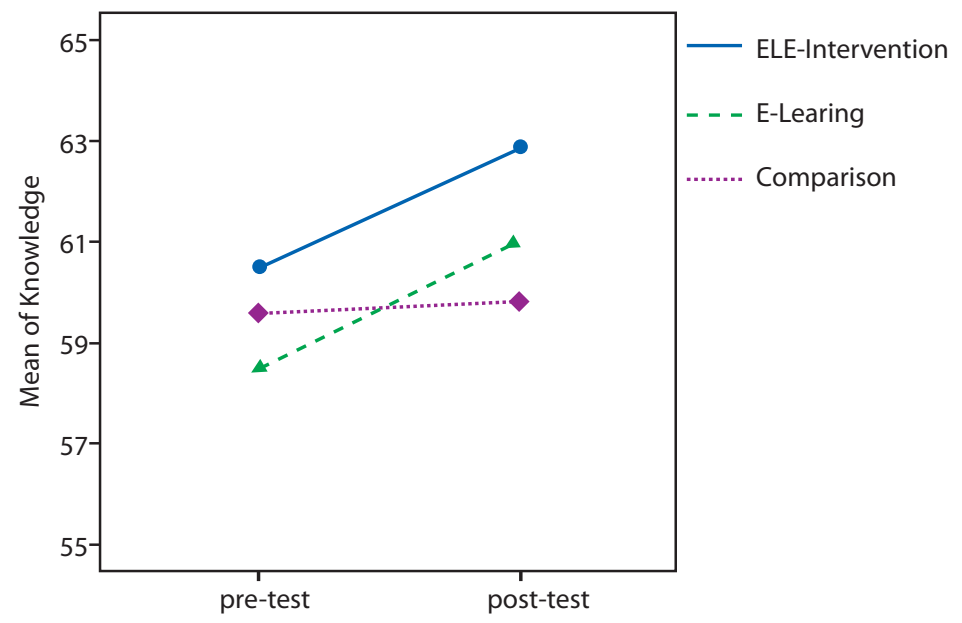

Figure 1. Changes within the groups knowledge scores between pre- and posttest.

\section{Changes in how to apply the knowledge to challenging interaction situations}

The results of repeated measures GLM regarding Case 1 (decreased productivity) indicated a significant positive change across all groups $[F(1.74)=15.89$, $p<.001$, partial $\left.\eta^{2}=.177\right]$ as well as statistically significant interaction between the training (i.e., pre- and post-test) and the group $[F(2.74)=5.19, p=.008$, partial $\left.\eta^{2}=.123\right]$. However, when examining the nature of the interaction and to determine in which groups the significant differences between the mean scores of the pre-and post-tests were, it was found that the change was significant both in the ELE intervention group $[F(1.74)=10.54, p=.002$, partial $\left.\eta^{2}=.125\right]$ and in the E-learning group $[F(1.74)=12.15, p=.001$, partial $\left.\eta^{2}=.141\right]$ but not in the comparison group $[F(1.74)=.04, p=.848$, partial $\eta^{2}=.000$ ] (see Figure 2). 


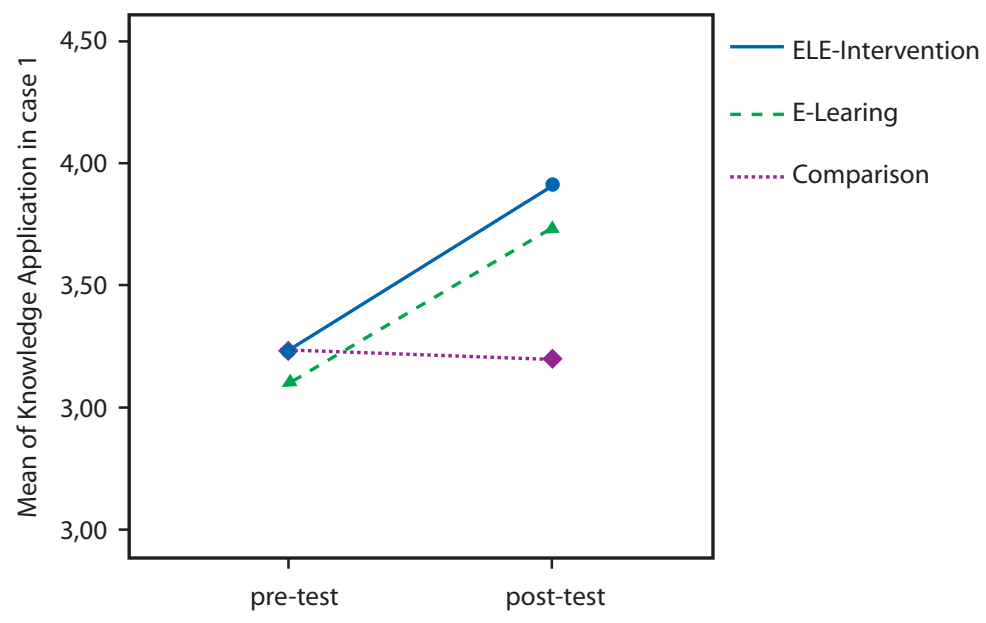

Figure 2. Changes within the groups in Case 1 (decreased productivity) scores between pre- and post-test.

Similarly, the scores of Case 2 (changed behaviour) showed a significant improvement during the ELE-training $[F(1.72)=7.49, p=.008$, partial $\left.\eta^{2}=.094\right]$ and statistically significant interaction between the training and the group $\left[F(2.72)=7.12, p=.002\right.$, partial $\left.\eta^{2}=.165\right]$. This time, however, the significant change was found only among the participants of the ELE intervention group $\left[F(1.72)=14.34, p<.001\right.$, partial $\left.\eta^{2}=.166\right]$. Accordingly, the change during the training was not significant neither among the E-learning group $\left[F(1.72), p=.115\right.$, partial $\left.\eta^{2}=.034\right]$ nor the comparison group $[F(1.72)=1.51$, $p=.224$, partial $\left.\eta^{2}=.020\right]$ (see Figure 3).

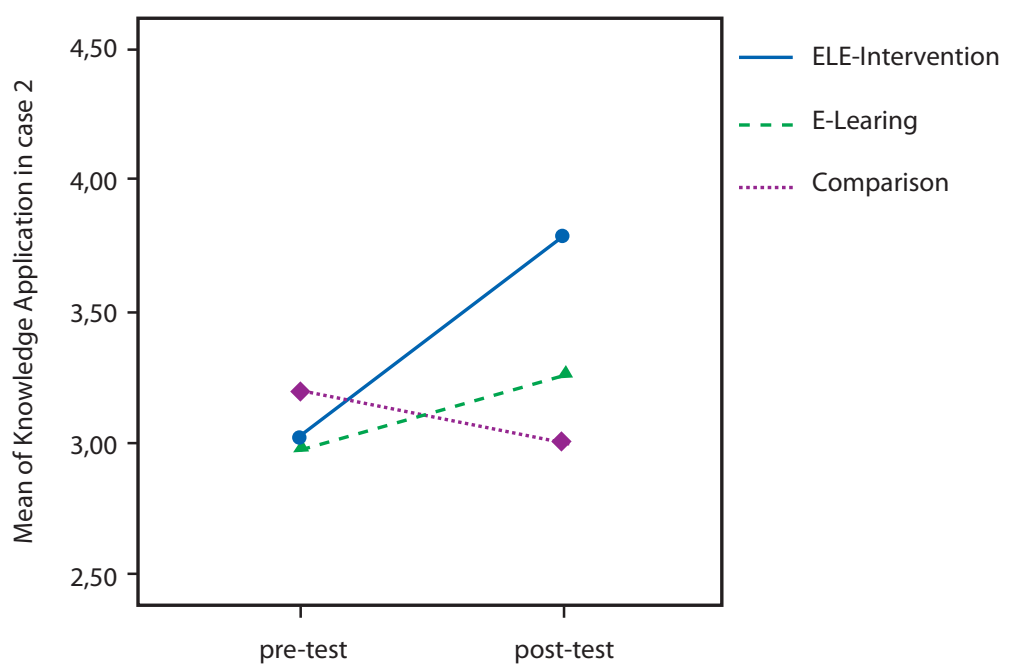

Figure 3. Changes within the groups in Case 2 (changed behaviour) scores between pre- and post-test. 
Finally, the results of GLM regarding Case 3 (poor atmosphere) revealed that the effect of the training was not statistically significant in any of the groups. A slight positive improvement was found in the answers of the ELE intervention group but it was not statistically significant $[F(1.71)=2.37, p=.129]$ (see Figure 4).

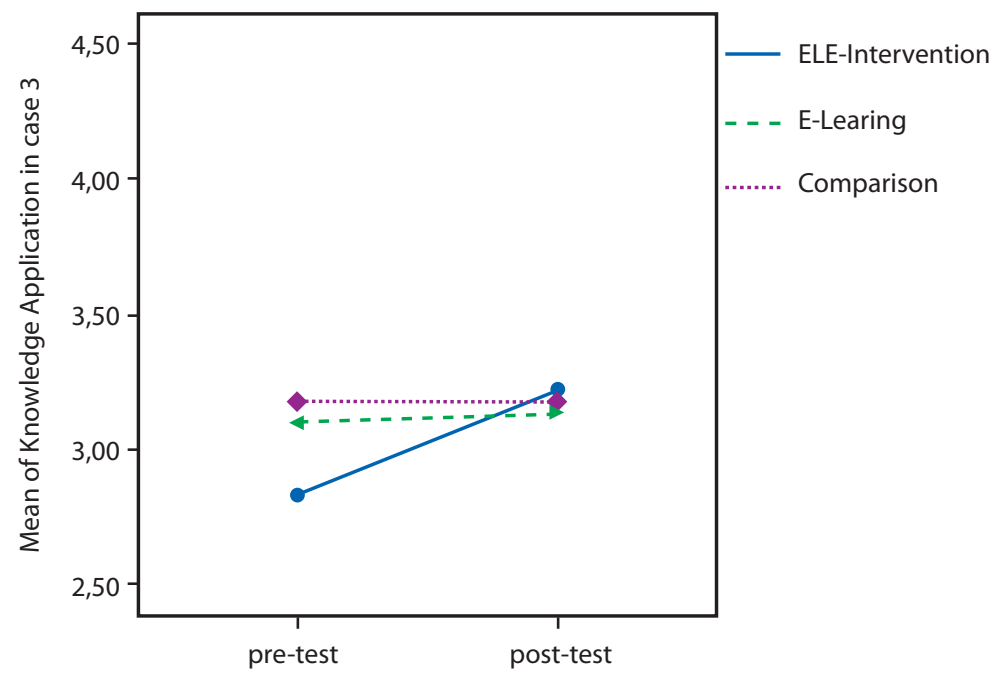

Figure 4. Changes between the groups in Case 3 (poor atmosphere) scores between pre- and post-test.

\section{Discussion}

The comparison group did not differ from the other two groups at the beginning of the intervention in terms of their knowledge of strategy or their readiness to solve challenging problems in human interaction. This indicates that even though the ELE Intervention group was selected by the company based on being promising future leaders, they did no better in the pre-tests than the other two groups.

The first research question was about the difference between the E-learning group and the comparison group. In terms of the knowledge about the strategy, during the training the E-learning group improved significantly more than the comparison group. Also, when solving Case 1, about how to react to a situation where an employee's quality of work had declined, the E-learning group improved significantly, whereas there was no change in the comparison group.

The second research question was whether the ELE Intervention group would differ from the other two groups. It appeared that in Case 1, both the 
E-learning and the ELE intervention groups improved their knowledge application significantly more than the comparison group. In addition, only the ELE intervention group improved their applied knowledge in Case 2, where an employee's behavioural problems were dealt with (long working days, lack of communication, and unexplained absence). No significant changes were found during the training, in terms of these measures among the participants of the comparison group.

No statistically significant changes could be perceived in the participants' answers to Case 3, not even in the ELE intervention group. This case was about how to deal with lack of respect and poor atmosphere in the workplace. This case did not test the social interaction skills that had been learned in ELE training but rather, a more general ability to lead group dynamics and improve group spirit. In the pre-test, there was a rich variation of approaches to the answers in this case, because the participants used their previous experiences instead of specific theory. That variation remained about the same, probably because ELE training did not provide enough frame and concrete tools to deal with this very complex subject.

\section{Limitations of the study}

The main limitation of this study was that it was not possible to randomise all groups. We did not have control over whom the company wanted to recruit in the ELE intervention group. The complex real-life setting was both an asset and a challenge with this study. There is always a trade-off in trying to maximise an authentic learning experience simultaneously with scientific rigor. It follows that the most robust results concern the differences between the e-learning group and the comparison group.

Further, we do not know if the learning outcomes will be transferred into real situations. There is a risk that the knowledge remains inert, but we tried to minimise this, since the trainees were expected to use the knowledge in the workplace and the context was kept as authentic as possible (Gegenfurtner et al., 2009). On the other hand, observing or taking video clips of challenging situations would give interesting information about possible transfer. There is a base-rate problem since these situations are quite rare and it would be difficult to capture real situations from moments when data are collected. Asking the employees' perceptions or asking them to write diaries about their managers' possible behavioural change might be difficult as well because of the infrequency of such situations.

Another limitation is that we do not know how long lasting are the reported effects of the training. However, we believe that the participants of the train- 
ing have learned to recognise more constructive ways of communicating with their employees, and that if they have time to think of ways of confronting the employee, they will utilise the knowledge and skills studied in the training. It might be possible to ask the participants after, for example, one year what they remember about the course and ask them to describe a challenging situation where they have used the knowledge and skills studied on the course. This kind of self-report would reflect quite well the perceived long-term effects of the training for the participant (see Talvio et al., 2014). After this intervention the company went through a major merger, which made it impossible to follow the participants.

\section{Conclusions and implications}

One of the strengths of the study was that the quasi-experimental research design. Furthermore, in the analyses phase the researchers did not know, whether the qualitative answers on dealing with challenging interaction situations were given before or after the training, and whether they were given by the ELE intervention group, the E-learning group or the comparison group. Therefore, the researchers were unbiased in their classifications.

The present study showed that complex communication skills could be studied and learned in both an e-learning and blended learning environment (Case 1). Further, some forms of social interaction skills were more effectively learned when face-to-face workshops were included (also Case 2). In this sense, the blended ELE training appeared more effective than the e-learning environment.

The benefit of the ELE intervention, however, was much more than adding face-to-face interaction to e-learning. It was a hybrid, deepening learning process based on our best understanding of modern pedagogical practices (Lonka, 2012; Tynjälä, 2013). The face-to-face group discussions and peer learning during workshops were also central. The participants expressed the opinion that face-to-face meetings were of more value than online chats. In learning communication skills, the experiential learning demonstrations and simulations by the trainer and the professional actors may have deepened the learning compared to studying the material alone by going through online video clips.

It was important that the whole intervention was integrated within the workplace environment and the skills training given was directly related to the work of the middle managers. It was comforting to notice that even in the most difficult cases, those who participated in training showed significant improvement in their readiness to deal with challenging situations. This experience 
gave us some important lessons about how to engage high-level professionals in a profound, authentic learning process.

The main findings of the study:

- It is important to create e-learning and blended learning environments that are based on modern educational theories and models;

- Engaging Learning Environment (ELE) model was used to implement a corporate strategy and foster social interaction skills of middle managers;

- The research design was quasi-experimental with an e-learning group, a blended learning group and a comparison group;

- Authentic case-based evaluation methods were developed to measure how to deal with challenging interactions in the workplace;

- In a pedagogically designed environment, middle managers learned how to put their corporate strategy into action.

\section{Acknowledgments}

Funding for this research was provided by the Academy of Finland project 308352, and an EU Erasmus+ project Learning2Be 4120034. The sabbatical leave of the first author was funded by the Jenni and Antti Wihuri Foundation as well as by the Academy of Finland Mobility Fund 318353.

\section{References}

Arnold, K. A., Turner, N., Barling, J., Kelloway, E. K., \& McKee, M. C. (2007). Transformational leadership and psychological well-being: The mediating role of meaningful work. Journal of Occupational Health Psychology, 12(3), 193-203. https://doi.org/10.1037/1076-8998.12.3.193

Aspegren, K. (1999). BEME Guide No. 2: Teaching and learning communication skills in medicine: A review with quality grading of articles. Medical Teacher, 21(6), 563-570. https://doi.org/10.1080/01421599978979

Bass, B. M., \& Riggio, R. E. (2006). Transformational leadership (2nd ed.). Mahwah: Erlbaum.

Batalla-Busquets, J.-M., \& Pacheco-Bernal, C. (2013). On-the-job e-learning: Workers' attitudes and perceptions. International Review of Research in Open \& Distance Learning, 14(1), 40-64. https://doi.org/10.19173/irrodl.v14i1.1304

Bereiter, C., \& Scardamalia, M. (1993). Surpassing ourselves: An inquiry into the nature and implications of expertise. Chicago: Open Court.

Bonk, C. J., \& Graham, C. R. (2006). The handbook of blended learning: Global perspectives, local designs. San Francisco: John Wiley \& Sons.

Brown, R. F., \& Bylund, C. L. (2008). Communication skills training: Describing a new conceptual model. Academic Medicine, 83(1), 37-44.

https://doi.org/10.1097/ACM.0b013e31815c631e 
Cegala, D. J., \& Broz, S. L. (2002). Physician communication skills training: A review of theoretical backgrounds, objectives and skills. Medical Education, 36(11), 1004-1016. https://doi.org/10.1046/j.1365-2923.2002.01331.x

Dweck, C. S. (2006). Mindset: The new psychology of success. New York: Random House.

Ericsson, K. A., \& Lehmann, A. C. (1996). Expert and exceptional performance: Evidence of maximal adaptation to task constraints. Annual Review of Psychology, 47(1), 273-305. https://doi.org/10.1146/annurev.psych.47.1.273

Ericsson, K. A., \& Smith, J. (Eds.) (1991). Toward a general theory of expertise: Prospects and limits. New York: Cambridge University Press.

Ericsson, K. A., Prietula, M. J., \& Cokely, E. T. (2007). The making of an expert. Harvard Business Review, 85(7/8), 114-121.

Frey, L. R., Botan, C. H., Friedman, P. G., \& Kreps, G. L. (1992). Interpreting communication research: A case study approach. Englewood Cliffs: Prentice Hall.

Gegenfurtner, A., Veermans, K., Festner, D., \& Gruber, H. (2009). Motivation to transfer training: An integrative literature review. Human Resource Development Review, 8(3), 403-423. https://doi.org/10.1177/1534484309335970

Gordon, T. (2001). Leader Effectiveness Training (L.E.T.): The proven people skills for today's leaders tomorrow. New York: Penguin Putnam.

Gordon, T. (2003). Teacher effectiveness training. New York: Three Rivers Press.

Grant, A. M., Christianson, M. K., \& Price, R. H. (2007). Happiness, health, or relationships? Managerial practices and employee well-being tradeoffs. Academy of Management Perspectives, 21(3), 51-63. https://doi.org/10.5465/amp.2007.26421238

Grossman, R., Salas, E., Pavlas, D., \& Rosen, M. A. (2013). Using instructional features to enhance demonstration-based training in management education. Academy of Management Learning \& Education, 12(2), 219-243. https://doi.org/10.5465/amle.2011.0527

Hakkarainen, K., Palonen, T., Paavola, S., \& Lehtinen, E. (2004). Communities of networked expertise: Professional and educational perspectives. Amsterdam: Pergamon.

Hidi, S., \& Renninger, K. A. (2006). The four-phase model of interest development. Educational Psychologist, 41(2), 111-127. https://doi.org/10.1207/s15326985ep4102_4

Hlupic, V. (2014). The management shift: How to harness the power of people and transform your organization for sustainable success. Basingstoke: Palgrave MacMillan. https://doi.org/10.1057/9781137352958

Hodges, B. (2006). Medical education and the maintenance of incompetence. Medical Teacher, 28(8), 690-696. https://doi.org/10.1080/01421590601102964

Hotho, S., \& Dowling, M. (2010). Revisiting leadership development: The participant perspective. Leadership \& Organisation Development Journal, 31(7), 609-629. https://doi.org/10.1108/01437731011079655

Ketonen, E., Talvio, M., \& Lonka, K. (2014). Engaging Learning Environment (ELE) for leadership training: Fostering interest and epistemic change. 2014 International Conference on Advanced Education and Management (ICAEM2014) (pp. 104-111). Lancaster: DEStech Publications. 
Knowles, M. S. (1980). The modern practice of adult education: From pedagogy to andragogy. New York: Cambridge Books.

Kolb, D. A. (1984). Experiential learning: Experience as the source of learning and development. Englewood Cliffs: Prentice-Hall.

Leader effectiveness training L.E.T. $(n . d$.). Retrieved from http://www.gordontraining.com/leader-effectiveness-training-l-e-t/.

Lonka, K. (2012). Engaging learning environments for the future: The 2012 Elizabeth W. Stone lecture. In R. Gwyer, R. Stubbings, \& G. Walton (Eds.), The road to information literacy: Librarians as facilitators of learning (pp. 15-30). Berlin, Munich: De Gruyter Saur.

Lonka, K. (2018). Phenomenal learning from Finland. Keuruu: Edita Publishing.

Lonka, K., \& Ahola, K. (1995). Activating instruction: How to foster study and thinking skills in higher education. European Journal of Psychology of Education, 10(4), 351-368. https://doi.org/10.1007/BF03172926

Lonka, K., \& Ketonen, E. (2012). How to make a lecture course an engaging learning experience? Studies for the Learning Society, 2(2/3), 63-74.

Lonka, K., Olkinuora, E., \& Mäkinen, J. (2004). Aspects and prospects of measuring studying and learning in higher education. Educational Psychology Review, 16(4), 301-323. https://doi.org/10.1007/s10648-004-0002-1

Marton, F., Dall'Alba, G., \& Beaty, E. (1993). Conceptions of learning. International Journal of Educational Research, 19(3), 277-300.

Marttinen, K., Patala, T., Ketonen, E., Ruusunen, R., \& Lonka, K. (2012). Students' and teachers' perceptions of an innovative blended learning environment - Case Porvoo Campus. Open learning generations. Closing the gap from "generation $y$ " to the mature lifelong learners. Paper presented in EDEN Annual Conference. Porto, Portugal.

Mezirow, J. (1991). Transformative dimensions of adult learning. San Francisco: Jossey-Bass.

Mortagy, Y., \& Boghikian-Whitby, S. (2010). A longitudinal comparative study of student perceptions in online education. Interdisciplinary Journal of E-Learning \& Learning Objects, 6(1), 23-44. https://doi.org/10.28945/1128

Muis, K. R., Pekrun, R., Sinatra, G. M., Azevedo, R., Trevors, G., Meier, E., \& Heddy, B. C. (2015). The curious case of climate change: Testing a theoretical model of epistemic beliefs, epistemic emotions, and complex learning. Learning and Instruction, 39, 168-183. https://doi.org/10.1016/j.learninstruc.2015.06.003

Mumford, M. D., Zaccaro, S. J., Connelly, M. S., \& Marks, M. A. (2000). Leadership skills: Conclusions and future directions. Leadership Quarterly, 11(1), 155-170. https://doi.org/10.1016/S1048-9843(99)00047-8

Paavola, S., Lipponen, L., \& Hakkarainen, K. (2004). Modeling innovative knowledge communities: A knowledge-creation approach to learning. Review of Educational Research, 74(4), 557-576. https://doi.org/10.3102/00346543074004557

Paechter, M., \& Maier, B. (2010). Online or face-to-face? Students' experiences and preferences in e-learning. Internet \& Higher Education, 13(4), 292-297. https://doi.org/10.1016/j.iheduc.2010.09.004 
Pekrun, R. (2005). Progress and open problems in educational emotion research. Learning and Instruction, 15(5), 497-506. https://doi.org/10.1016/j.learninstruc.2005.07.014

Renkl, A., Mandl, H., \& Gruber, H. (1996). Inert knowledge: Analyses and remedies. Educational Psychologist, 31(2), 115-121. https://doi.org/10.1207/s15326985ep3102_3

Ryan, R. M., \& Deci, E. L. (2002). Overview of self-determination theory: An organismic-dialectical perspective. In E. L. Deci \& R. M. Ryan (Eds.), Handbook of self-determination research (pp. 3-33). Rochester: University of Rochester Press.

Sandström, N., Eriksson, R., Lonka, K., \& Nenonen, S. (2016). Usability and affordances for inquiry-based learning in a blended learning environment. Facilities, 34(7/8), 433-449. https://doi.org/10.1108/F-12-2014-0097

Talvio, M. (2014). How do teachers benefit from training on interaction skills? Developing and utilising an instrument to evaluate teachers' social and emotional learning (Doctoral dissertation). Helsinki: University of Helsinki. Retrieved from http://urn.fi/URN:ISBN:978-951-51-0188-4.

Talvio, M., Ketonen, E., \& Lonka, K. (2014). How long lasting are the effects of training on interaction skills? Teachers' sample. In 2014 International Conference on Advanced Education and Management (ICAEM2014) (pp. 125-131). Lancaster: DEStech Publications.

Talvio, M., Lonka, K., Komulainen, E., Kuusela, M., \& Lintunen, T. (2012). The development of the Dealing with Challenging Interaction (DCI) method to evaluate teachers' social interaction skills. Procedia - Social and Behavioral Sciences, 69(24), 621-630. https://doi.org/10.1016/j.sbspro.2012.11.454

Talvio, M., Lonka, K., Komulainen, E., Kuusela, M., \& Lintunen, T. (2013). Revisiting Gordon's teacher effectiveness training: An intervention study on teachers' social and emotional learning. Electronic Journal of Research in Educational Psychology, 11(3), 693-716.

Talvio, M., Lonka, K., Komulainen, E., Kuusela, M., \& Lintunen, T. (2015). The development of teachers' responses to challenging situations during interaction training. Teacher Development, 19(1), 97-115.

https://doi.org/10.1080/13664530.2014.979298

Teacher effectiveness training T.E.T. ( $n$. d.). Retrieved from http://www.gordontraining.com/school-programs/teacher-effectiveness-training-t-e-t/.

Trilling, B., \& Fadel, C. (2009). 21st century skills: Learning for life in our times. San Francisco: John Wiley \& Sons.

Tynjälä, P. (2008). Perspectives into learning at the workplace. Educational Research Review, 3(2), 130-154. https://doi.org/10.1016/j.edurev.2007.12.001

Tynjälä, P. (2013). Toward a 3-P model of workplace learning: A literature review. Vocations and Learning, 6(1), 11-36. https://doi.org/10.1007/s12186-012-9091-z

Vaara, L. J. (2018). Young business generations - a technology-mediated application of the Engaging Learning Model. K. Lonka (Ed.), Phenomenal learning from Finland (pp. 154-155). Keuruu: Edita Publishing. 
Van Dierendonck, D., Haynes, C., Borrill, C., \& Stride, C. (2004). Leadership behavior and subordinate well-being. Journal of Occupational Health Psychology, 9(2), 165175. https://doi.org/10.1037/1076-8998.9.2.165

Vermunt, J. D. (1995). Process-oriented instruction in learning and thinking strategies. European Journal of Psychology of Education, 10(4), 325. https://doi.org/10.1007/BF03172925

Wall, J., \& Ahmed, V. (2008). Lessons learned from a case study in deploying blended learning continuing professional development. Continuing professional development. Engineering, Construction and Architectural Management, 15(2), 185-202. https://doi.org/10.1108/09699980810852691

Weber, R. P. (1990). Basic content analysis (2nd. ed.). Beverly Hills: Sage. https://doi.org/10.4135/9781412983488

Wenger, E. (1999). Communities of practice: Learning, meaning, and identity. Cambridge: Cambridge University Press. 